\title{
$X: 47176761-47187553$
}

National Cancer Institute

\section{Source}

National Cancer Institute. X:47176761-47187553. NCI Thesaurus. Code C41710.

Physical location of ARAF1_Gene 